\title{
Subalpine Fir (Abies laciocarpa) and Norway Spruce (Picea abies) Seedlings Show Different Growth Responses to Blue Light
}

\author{
Hazel Navidad ${ }^{1}$, Inger Sundheim Fløistad ${ }^{2}{ }^{(0}$, Jorunn E. Olsen ${ }^{1}$ and Sissel Torre ${ }^{1, *(1)}$ \\ 1 Department of Plant Sciences, Faculty of Bioscience, Norwegian University of Life Sciences, P.O. Box 5003, \\ N-1432 Ås, Norway; hnavidad@gmail.com (H.N.); jorunn.olsen@nmbu.no (J.E.O.) \\ 2 Norwegian Institute of Bioeconomy Research, P.O. Box 115, N-1431 Ås, Norway; inger.floistad@nibio.no \\ * Correspondence: sissel.torre@nmbu.no; Tel.: +47-6723-2828
}

Received: 2 April 2020; Accepted: 11 May 2020; Published: 15 May 2020

\begin{abstract}
Blue light (BL) affects different growth parameters, but information about the physiological effects of BL on conifer seedlings is limited. In northern areas, conifer seedlings are commonly produced in heated nursery greenhouses. Compared with Norway spruce, subalpine fir seedlings commonly show poor growth in nurseries due to early growth cessation. This study aimed to examine the effect of the BL proportion on the growth and development of such conifer seedlings in growth chambers, using similar photosynthetic active radiation, with $5 \%$ or $30 \%$ BL $(400-500 \mathrm{~nm})$ from high pressure sodium (HPS) lamps ( $\left.300 \mu \mathrm{mol} \mathrm{m}^{-2} \mathrm{~s}^{-1}\right)$ or a combination of HPS $\left(225 \mu \mathrm{mol} \mathrm{m}^{-2} \mathrm{~s}^{-1}\right)$ and BL-emitting diodes $\left(75 \mu \mathrm{mol} \mathrm{m} \mathrm{m}^{-2} \mathrm{~s}^{-1}\right)$, respectively. Additional BL increased transpiration and improved the growth of the Norway spruce seedlings, which developed thicker stems, more branches, and a higher dry matter (DM) of roots and needles, with an increased DM percentage in the roots compared with the shoots. In contrast, under additional BL, subalpine fir showed reduced transpiration and an increased terminal bud formation and lower DM in the stems and needles but no change in the DM distribution. Since these conifers respond differently to BL, the proportion of BL during the day should be considered when designing light spectra for tree seedling production.
\end{abstract}

Keywords: blue light; bud set; conifer seedlings; LED; light quality; root growth; shoot elongation; shoot growth; terminal bud formation; transpiration

\section{Introduction}

The production of conifer seedlings in northern areas such as the Nordic countries normally takes place in greenhouses with the use of artificial light during the first part of the cultivation phase. Robust and stress-tolerant plants with a well-developed root system are prerequisites for a successful seedling production and subsequent transplanting to the field [1,2]. During nursery cultivation, however, seedlings of species such as Norway spruce (Picea abies) and subalpine fir (Abies laciocarpa (Hooker) Nuttall) may root poorly, cease growth, and develop early terminal buds, resulting in less robust and smaller seedlings than desirable for forestry and Christmas tree production [2]. Early growth cessation is commonly the case for subalpine fir when grown under natural light in nurseries in the Nordic countries [3]. Light strongly influences the plant growth and development, and the manipulation of light is recognised as a possible tool to prevent or delay early bud set [4-6].

Experiments have shown that far-red (FR) light or a low red (R)/FR ratio provided as a low-intensity day-extension or night interruption (NI), or a low R/FR ratio during the day act as signals to prevent growth cessation and bud set in small seedlings of Norway spruce $[5,7,8]$. In this species, plants supplied with $\mathrm{R}$ light as a day-extension showed delayed bud set as compared with plants exposed 
to short days without a day-extension $[5,8]$. Responses may depend on the provenance and growth conditions [9,10]. Recently, the application of FR light as a day-extension provided by light emitting diodes (LEDs) was shown to delay the terminal bud formation in subalpine fir originating from $53.59^{\circ} \mathrm{N}$ latitude when grown in growth chambers within a temperature range between $18-24^{\circ} \mathrm{C}$ [3]. On the other hand, a day-extension with $\mathrm{R}$ light resulted in rapid bud set similar to the situation without a day extension [3].

The amount of blue light (BL) in the solar radiation changes daily and seasonally and accounts for approximately $15-20 \%$ of the visible light [11]. In a range of plant species, BL affects the photosynthesis efficiency and growth rate as well as morphological characteristics like branching, stem elongation, and root growth, as well as stress tolerance [12]. In Norway spruce, low irradiances of BL provided as a day-extension delayed the terminal bud formation $[7,13]$. However, in subalpine fir, no such effect of BL was observed [3]. In this study, all subalpine fir plants exposed to a day-extension with BL rapidly developed terminal buds similar to the situation without a day-extension. In Scots pine, the application of BL or R light during germination and hypocotyl development increased the fibre dimensions compared with FR or white light [13]. In that study, a higher rate of survival in the field was observed after exposure to BL, white, and R light as compared with FR light [13]. However, little attention has been paid to conifer responses to additional BL provided during the photosynthetic light period when the fractions of $\mathrm{R}$ and FR light are fixed. Although the phytochrome system absorbs a small proportion of BL in addition to $\mathrm{R}$ and FR light, BL is best known to act via the B/UV-A absorbing pigments' cryptochromes and phototropins $[14,15]$. The BL receptors, phototropins, regulate the stomata opening and transpiration, and promote plant growth in responses to BL in a low-light environment [16]. However, there are differences in the sensitivities of plant growth to BL, and too high a proportion of BL can lead to a reduced biomass accumulation and smaller plants depending on the species and background climate [17].

Currently, high-pressure sodium lamps (HPS) are the most common photosynthetic light source in greenhouses. However, these lamps provide very little BL (5\%), and a relatively high ratio of $\mathrm{R}$ $(660 \mathrm{~nm})$ to FR $(730 \mathrm{~nm})$ light compared with natural sunlight $(\mathrm{R} / \mathrm{FR} \approx 3.5 \mathrm{in}$ HPS and 1.1 in sunlight). The objective of this study was to evaluate the physiological effects of the BL (400-500 nm) proportion in the light spectrum during the day in small seedlings of Norway spruce and subalpine fir by using BL-emitting diodes (LEDs) combined with HPS lamps. Specifically, we tested if additional BL in the photosynthetic light could prevent a terminal bud formation and/or improve growth in these conifer species.

Closed growth chambers were used and the lighting conditions were designed to only change the proportion of $\mathrm{BL}$, not the total irradiance, and to provide a similar R/FR ratio and phytochrome photostationary state (PPS, according Sager et al. [18].

\section{Materials and Methods}

\subsection{Germination and Raising of Seedlings of Subalpine Fir and Norway Spruce}

Seeds of subalpine fir (Abies laciocarpa (Hooker) Nuttall) from the provenance CAN10 $\left(53.39^{\circ} \mathrm{N}\right.$ latitude, $122.23^{\circ} \mathrm{W}$ longitude, 1000-1200 m above sea level from "George Mountain" British Columbia, Canada; Seed lot F13-005, The Norwegian forest seed center, Hamar, Norway) were used. Before sowing, seeds were placed on moist filter paper in Petri dishes and stratified at $4{ }^{\circ} \mathrm{C}$ in the dark for three weeks. The seeds of Norway spruce were not stratified due to the reasonably even germination without stratification combined with access to sufficient seeds enabling the selection of even seedlings for the experiments. The stratified subalpine fir seeds along with the seeds of Norway spruce (P. abies (L.) H. Karst) from the provenance CØ1 from $59^{\circ} \mathrm{N}$ latitude, 0-149 $\mathrm{m}$ above sea level (Halden Østfold, Norway; seed lot 98063; The Norwegian forest seed center) were sown in plastic pots (pot diameter of $60 \mathrm{~mm}$, height $51 \mathrm{~mm}$ ) filled with a 3:1 mixture of peat (Degernes Vesksttorv, Torvstøfabrikk, Degernes, Norway) and perlite. The pots were watered with pure water when needed to keep an even soil 
humidity and prevent the drying of the soil. During the germination and raising of the seedlings prior to the start of the experimental treatments, the plants were kept in a greenhouse with a glass roof and polycarbonate walls at the Norwegian University of Life Sciences, Ås Norway $\left(59^{\circ} 39^{\prime} 47^{\prime \prime} \mathrm{N}\right.$ $10^{\circ} 47^{\prime} 38^{\prime \prime}$ E). For the first experiment, this took place from 3 June to 22 June 2015, and for a repeated experiment in July 2016. The average air temperature was $20^{\circ} \mathrm{C}\left( \pm 2{ }^{\circ} \mathrm{C}\right)$, and the average daily relative air humidity $(\mathrm{RH})$ was $70 \%( \pm 5 \%)$. The climate was controlled and monitored using a PRIVA system (Priva, De Lier, The Netherlands). Supplemental light was provided by HPS (Osram NAVT 400W, Munich, Germany), at an irradiance of $100 \mu \mathrm{mol} \mathrm{m}^{-2} \mathrm{~s}^{-1}$ for $16 \mathrm{~h}$ daily. The supplemental light was turned off automatically when the natural solar radiation was higher than $200 \mathrm{~W} \mathrm{~m}^{-2}$.

\subsection{Light Quality Treatments and Climatic Conditions during the Experimental Period}

After 19 days of pre-cultivation, the seedlings were transferred to two growth chambers with different light quality treatments (Figure 1 and Table 1). At the time of the transfer, the plant height of subalpine fir was $0.4-1.9 \mathrm{~cm}$ with $2-5$ needles, while the plant height of Norway spruce was $0.4-2.0 \mathrm{~cm}$ with $4-10$ needles. The experiment was performed twice with Norway spruce with similar results and once with subalpine fir. The two species were grown simultaneously in the same growth chambers. In the first experiment, 36 pots with Norway spruce seedlings and 18 pots with subalpine fir seedlings (one plant per pot) were used for each of the two treatments. In a repeated experiment, 15 pots with Norway spruce were used. A repeated experiment with Norway spruce only was due to enhanced growth in this species only in response to the increased BL proportion, while subalpine fir showed no growth stimulation whatsoever, only a high degree of bud set, consistent with previous experiments employing BL as a day-extension [3]. The light in the growth chambers was provided continuously ( $24 \mathrm{~h}$ ) by the use of HPS lamps ( $5 \%$ BL; $400 \mathrm{~W}$, Superagro system, Gavita, Andebu, Norway) enriched with 8 incandescent bulbs ( $50 \mathrm{~W}$ each, Osram, Munich, Germany). This ensured a photoperiod significantly longer than the critical one for sustained growth (prevention of bud set) for the northern Norway spruce provenance used $[9,19]$. Such long days were used in a range of previous physiological studies with northern provenances of Norway spruce and other woody species and are known to work well with no signs of negative effects on the growth and development ([9] and references therein). Additional BL was provided by LEDs in one of the chambers (400-500 nm, peak at $460 \mathrm{~nm}$, Philips green power, $100 \mathrm{~W}$, Phillips, The Netherlands). The photosynthetic active radiation (PAR) in both growth chambers was $300 \mu \mathrm{mol} \mathrm{m}{ }^{-2} \mathrm{~s}^{-1}$, as measured at the top of the plant canopy by a Li-Cor Quantum sensor (Model LI-250, Li-Cor, Lincoln, NE, USA). A higher, evenly distributed irradiance could not be obtained due to the technical limitations of the growth chambers, but using a $24 \mathrm{~h}$ photoperiod improved the total daily light sum. In the treatment with additional BL (HPS + BL), the blue LEDs provided about $75 \mu \mathrm{mol} \mathrm{m}{ }^{-2} \mathrm{~s}^{-1}$ of the total irradiance and the HPS lamps $225 \mathrm{~m}^{-2} \mathrm{~s}^{-1}$, ensuring equal total irradiance (equal light sum) to the treatment with HPS only (Table 1). The spectral distribution of the different light qualities (Figure 1) was measured using an OceanOptics SD2000 spectrometer (model SD2000, OceanOptics, Eerbeek, The Netherlands). The proportion of BL in the HPS + BL treatment was $30 \%$, calculated by adding the intensity of all wavelengths between 400-500 $\mathrm{nm}$ and then calculating the percentage of the total intensity between 400-700 nm (Figure 1, Table 1). The R/FR ratio was 3.5, as measured with a 660/730 sensor (Skye Instruments, Llandrindod, UK). The chamber temperature set point was $22^{\circ} \mathrm{C}\left( \pm 1^{\circ} \mathrm{C}\right)$ for $24 \mathrm{~h}$ a day and the average $\mathrm{RH}$ was $85 \%$. The plant temperature was measured close to the shoot apical meristem with an infrared sensor (Fluke 62 Max IR thermometer, Washington, USA). The carbon dioxide level was ambient (400 ppm) and the climate was controlled by a PRIVA computer as described above. The plants were watered with a nutrient solution (electric conductance (EC): $2.0 \mathrm{mS}$ ) containing Superba $9-5-25+4.2 \mathrm{Mg}+\mathrm{S}$ + Micro-nutrients and calcinit (Yara, Oslo, Norway), when required (according to the needs). 


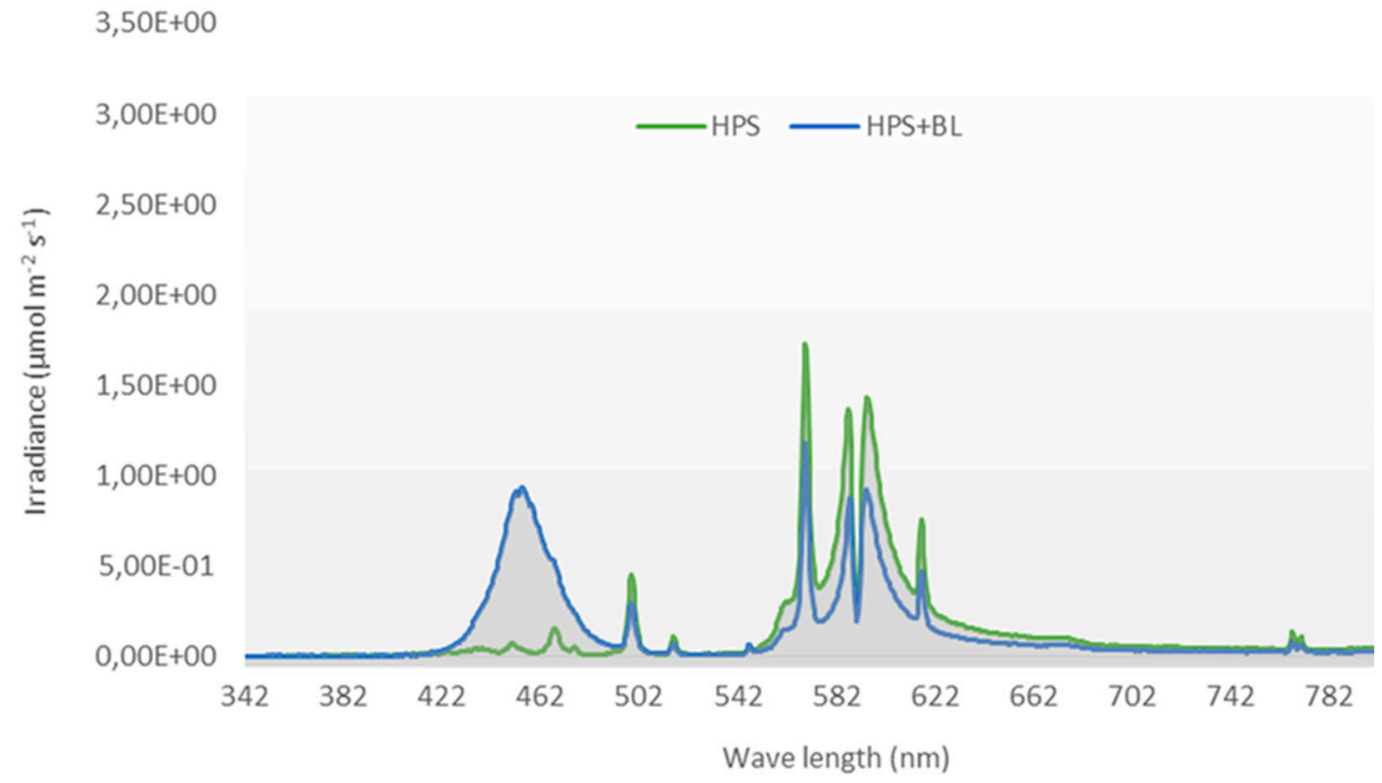

Figure 1. Light spectra of the lamps used in the study of Norway spruce and subalpine fir: Green line $=5 \%$ blue light (BL): High pressure sodium (HPS) lamps (Osram NAV T-400W). Blue line $=30 \%$ BL: HPS + blue light-emitting diodes (Philips GreenPower LED module HF Blue, Philips, Eindhoven, The Netherlands).

Table 1. Description of the light quality treatments in the two chambers used in the study of Norway spruce and subalpine fir. The main light source was high-pressure sodium (HPS) lamps (5\% blue light (BL)) and the $30 \%$ BL treatment (HPS + BL) was supplemented with blue LEDs.

\begin{tabular}{|c|c|c|c|c|c|c|}
\hline \multirow[t]{2}{*}{ Blue Light * } & \multicolumn{2}{|c|}{ 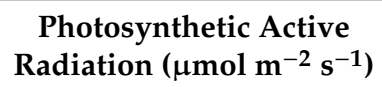 } & \multirow[t]{2}{*}{ Total PAR } & \multirow[t]{2}{*}{ R/FR } & \multirow[t]{2}{*}{ PPS ** } & \multirow[t]{2}{*}{ Plant Temperature $\left({ }^{\circ} \mathrm{C}\right) * * *$} \\
\hline & HPS & Blue LED & & & & \\
\hline $5 \%$ & 300 & - & 300 & 3.5 & 0.70 & 22 \\
\hline $30 \%$ & 225 & 75 & 300 & 3.5 & 0.70 & 22 \\
\hline
\end{tabular}

* The amount (\%) of BL was calculated by adding the intensity of all wavelengths between $400-500 \mathrm{~nm}$ and then calculating the percentage of the total intensity between $400-700 \mathrm{~nm}$. ${ }^{* *}$ The phytochrome photostationary state (PPS) was calculated according to Sager, Smith, Edwards, and Cyr [17]. *** Plant temperature was measured with an infra-red sensor in the shoot apical region of the seedlings. PAR= photosynthetic active radiation, R/FR= red/far red ratio.

\subsection{Recordings of Growth and Morphology}

The height of eighteen randomly chosen seedlings from each species was measured weekly from the rim of the pots up to the shoot apical meristem every week during the experimental period of 9 weeks and the cumulative growth was calculated. Aiming at shedding light on how the BL proportion in the light spectrum affects growth and development, rather than simulating an entire culture period in nurseries (commonly 20-25 weeks), the experiment was terminated after stable effects had manifested. After 9 weeks of growth, the final total plant height from the soil to the shoot apical meristem was measured, the number of needles counted, and the stem diameter measured in the middle of the stem using a digimatic vernier caliper (Model CD-15D, Pluss Mitutoyo Corporation, Kanagawa, Japan). Further, the number of plants with terminal buds was scored using a binocular (light green or brown bud scales $=1$, no terminal bud $=0$ ) and the number of lateral branches was counted and their lengths measured. The roots, stem, and needles were then separated and the roots were carefully washed free of soil. Then, the length of the longest root was measured. The needles, stem, and roots of individual plants were dried at $56{ }^{\circ} \mathrm{C}$ for about 1 week before the dry weight (DW) measurements. 


\subsection{Recordings of Seedling Transpiration}

Water usage (mg water/needle/h) was measured on 5 seedlings per species per treatment at the end of the experiment, i.e., when the plants were close to 9-weeks-old. The pots, which all had equal sizes, were covered with aluminium foil to avoid water loss from the soil and the plants were weighed twice within a $20 \mathrm{~h}$ interval. The weight was measured $30 \mathrm{~min}$ after the plants were watered and again $4 \mathrm{~h}$ before the next watering. The measurements were taken for 3 consecutive days before the destructive harvest. The water usage was calculated by dividing the water loss (in $\mathrm{mg}$ ) by the number of needles and hours.

\subsection{Statistical Analyses}

The statistical analysis was conducted using an analysis of variance (ANOVA) in Minitab (Version 16, Minitab Inc., Coventry, UK). Means were separated using Tukey's test at the $5 \%$ level of significance. A nonparametric Mann-Whitney test was used to test the effects of light quality on the number of terminal buds developed in subalpine fir at $p=0.05$. This nonparametric test was used to meet the assumptions on data distribution. The experiment was performed twice with Norway spruce with similar results and once with subalpine fir. Data from the first replicate were used in the statistical analysis. Hence, the comparisons were based on pseudoreplicates rather than on true replicates.

\section{Results}

Bud Formation, Morphology and Transpiration Rate of the Seedlings

The Norway spruce seedlings did not develop terminal buds during the experimental period in the light treatments. On the other hand, at the end of the experiment, $38 \%$ of the subalpine fir seedlings had developed light green/brown buds when exposed to $30 \% \mathrm{BL}$, a significantly $(p<0.05)$ higher frequency compared with the seedlings exposed to $5 \%$ BL (9\% with terminal buds; Table 2).

Table 2. Effect of the blue light (BL) proportion on the development of terminal buds, shoot elongation (cumulative growth), morphology, root length $(\mathrm{cm})$, and transpiration rate of Norway spruce and subalpine fir after 9 weeks of growth under continuous lighting of $300 \mu \mathrm{mol} \mathrm{m}^{-2} \mathrm{~s}^{-1}$ using HPS lamps $(5 \% \mathrm{BL})$ only or HPS + blue LED (30\% BL) resulting in a similar red (R)/far-red (FR) light ratio and phytochrome photostationary state (PPS). The two species were analysed separately and means in the different treatments not sharing a letter are significantly different $(p<0.05), n=18$ (mean \pm SE).

\begin{tabular}{|c|c|c|c|c|}
\hline & \multicolumn{2}{|c|}{ Norway Spruce } & \multicolumn{2}{|c|}{ Subalpine Fir } \\
\hline & $5 \% \mathrm{BL}$ & $30 \% \mathrm{BL}$ & $5 \% \mathrm{BL}$ & $30 \% \mathrm{BL}$ \\
\hline Plants with terminal buds (\%) & 0 & 0 & $9 \mathrm{a}$ & $38.0 \mathrm{~b}$ \\
\hline Shoot elongation $(\mathrm{cm})$ & $4.40 \pm 0.26 \mathrm{a}$ & $4.03 \pm 0.29 \mathrm{a}$ & $1.12 .52 \pm 0.12 \mathrm{a}$ & $1.22 \pm 0.07 \mathrm{a}$ \\
\hline Stem diameter $(\mathrm{mm})$ & $1.61 \pm 0.11 \mathrm{a}$ & $1.98 \pm 0.11 b$ & $1.44 \pm 0.08 \mathrm{a}$ & $1.50 \pm 0.05 a$ \\
\hline No of branches & $2.70 \pm 0.15 a$ & $4.70 \pm 0.36 \mathrm{~b}$ & 0 & 0 \\
\hline Length of branches & $1.34 \pm 0.09 \mathrm{a}$ & $1.60 \pm 0.12 \mathrm{a}$ & - & - \\
\hline Average number of needles per seedling & $179.2 \pm 14.7 \mathrm{a}$ & $234.2 \pm 17.1 b$ & $36.2 \pm 4.93 \mathrm{a}$ & $51.0 \pm 6.66 \mathrm{a}$ \\
\hline $\begin{array}{l}\text { Shoot transpiration rate } \\
\left(\mathrm{mg} \mathrm{H}_{2} \mathrm{O} \text { per needle } \mathrm{h}^{-1}\right)\end{array}$ & $0.0006 \pm 0.00 \mathrm{a}$ & $0.0014 \pm 0.00 b$ & $0.004 \pm 0.00 \mathrm{a}$ & $0.003 \pm 0.00 b$ \\
\hline Root length $(\mathrm{cm})$ & $16.73 \pm 2.28 \mathrm{a}$ & $13.07 \pm 1.56 b$ & $11.32 \pm 1.48 \mathrm{a}$ & $8.75 \pm 0.79 \mathrm{a}$ \\
\hline
\end{tabular}

All plants increased in height during the experimental period, but did not differ between the light quality treatments (results not shown). Thus, the total stem height at the end of the experiment was also not affected by the light treatment for either species (Table 2). Additional B light increased the number of needles per plant significantly in Norway spruce (Table 2). A similar trend was noticeable in subalpine fir, although was not statistically significant $(p>0.05)$ (Table 2). In Norway spruce, the number of branches and the average stem diameter was significantly thicker when exposed to $30 \%$ 
BL compared with 5\% BL (Table 2). Subalpine fir did not show any difference in the stem diameter and did not produce any branches (Table 2).

The transpiration rate in Norway spruce was about 50\% higher for seedlings exposed to $30 \%$ BL compared with those exposed to $5 \%$ BL (Table 2). In contrast, subalpine fir showed $20 \%$ lower transpiration under additional BL (Table 2).

Additional BL resulted in an increased root DW (3.8-fold) and reduced the length of the root system (1.3-fold) in the Norway spruce seedlings but had no effect on the root development of the subalpine fir seedlings (Figure 2).

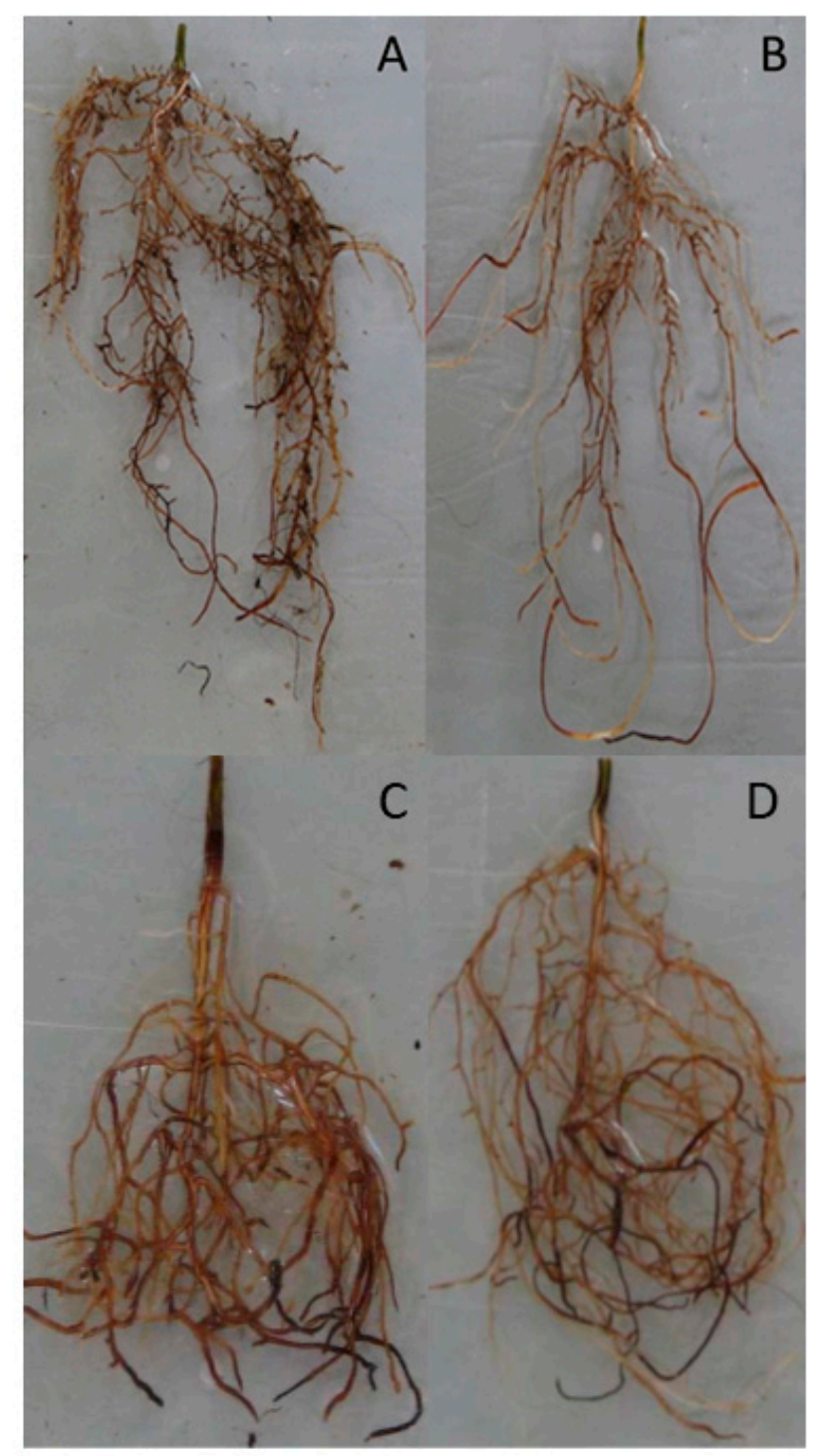

Figure 2. Effect of the blue light (BL) proportion on the root morphology in Norway spruce $(\mathbf{A}, \mathbf{B})$ and subalpine fir (C,D) after 9 weeks of growth under a continuous lighting of $300 \mu \mathrm{mol} \mathrm{m}{ }^{-2} \mathrm{~s}^{-1}$ using HPS + blue LED $(30 \%$ BL) $(\mathbf{A}, \mathbf{C})$ or HPS lamps $(5 \%$ BL) $(\mathbf{B}, \mathbf{D})$ only, with both resulting in a similar R/FR ratio and phytochrome photostationary state (PPS).

When exposed to $30 \% \mathrm{BL}$, the Norway spruce seedlings had a significantly $(p<0.05)$ higher DW $(+78 \%)$, whereas subalpine fir had a significantly lower DW (-35\%) as compared with 5\% BL (Figure 3 ). The Norway spruce seedlings exposed to $30 \%$ BL allocated more DM to the roots compared with plants exposed to $5 \%$ BL (17\%) (Figure 3A). In subalpine fir, the DM distribution was very similar between the two light quality treatments (Figure 3B). 


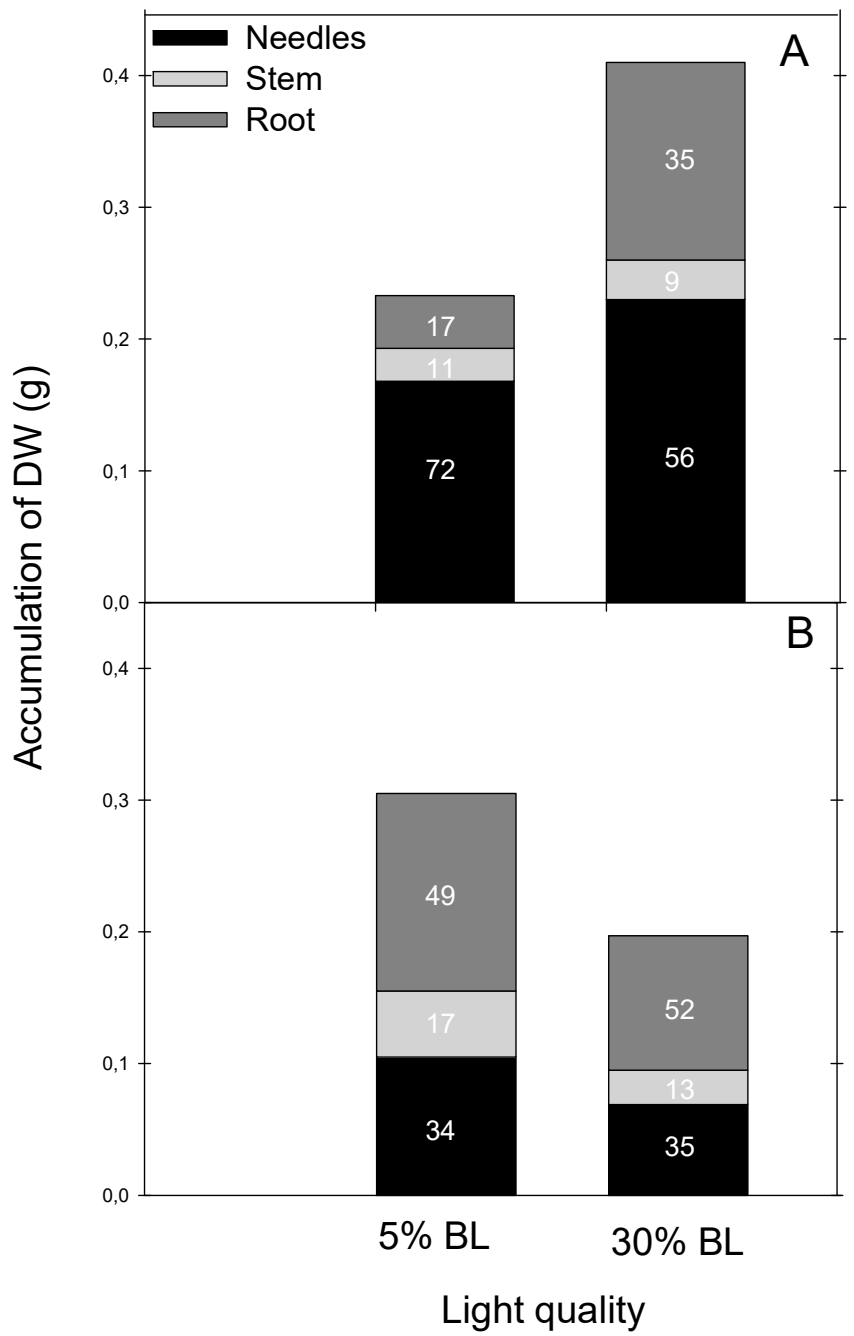

Figure 3. Effect of the blue light (BL) proportion on the accumulation of the dry weight (DW) (g) and distribution (\%, numbers in the bars) between the needles, stem, and root of the Norway spruce (A) and subalpine fir (B) seedlings after 9 weeks of growth under a continuous lighting of $300 \mu \mathrm{mol} \mathrm{m}^{-2} \mathrm{~s}^{-1}$ using HPS lamps (5\% BL) or HPS + blue LED (30\% BL) resulting in a similar R/FR ratio and phytochrome photostationary state (PPS), $n=10$.

\section{Discussion}

The use of novel lighting technology like LEDs makes it easier to optimise the spectral composition according to the requirements of specific species. Further, new technologies based on pre-cultivation in mini-plugs and replugging robots demand favourable growing conditions, including light quality [20]. Different plant species, including the conifer species and provenances therein, may respond differently to light quality $[7,21,22]$. Furthermore, other growing conditions like temperature and photoperiod as well as irradiance are known to affect the responses to changes in light quality $[4,9,23]$. In this study, aiming at investigating the physiological effects of different BL proportions in the light spectrum, wavelengths (other than BL) known to affect terminal bud set, like FR light, the R/FR ratio, and PPS as well as PAR and needle temperature was similar in the two BL treatments tested $(5 \%$ and $30 \% \mathrm{BL}$, Table 1). The results showed that the small seedlings of subalpine fir and Norway spruce responded differently to different BL ratios in the photosynthetic light. As compared with 5\% BL, 30\% BL improved the growth and productivity of Norway spruce but promoted terminal bud set and inhibited the growth of subalpine fir. A high degree of bud set in subalpine fir under the increased BL proportion in the light spectrum is consistent with the situation under a day-extension with pure BL [3]. Hence, 
the proportion of BL in the photosynthetic light is important to take into consideration when designing light spectra for the seedlings of different conifer species.

In addition to its role as a primary energy source for photosynthesis, light acts as a photomorphogenic signal in both the shoots and roots of plants. BL is known to trigger a range of morphological responses such as suppressed shoot elongation and increased branching [12]. However, no morphological changes were observed in subalpine fir in response to BL, neither in the shoot or the $\operatorname{root}$ (Table 2, Figure 2). The seedlings exposed to 30\% BL showed a reduced biomass accumulation (DM) and more terminal buds compared with the plants exposed to 5\% BL (Table 2, Figure 2). Subalpine fir seedlings are highly shade tolerant and can establish under a closed canopy [24]. It may be possible that the high proportion of BL was sensed by the seedlings as light stress resulting in photoinhibition and suppressed photosynthesis [25]. The irradiance in the present experiment was only $300 \mu \mathrm{mol} \mathrm{m}{ }^{-2} \mathrm{~s}^{-1}$, which results in relatively low photosynthesis rates. On the other hand, the photoperiod was $24 \mathrm{~h}$, resulting in a rather high total light sum during the experiment.

Enhanced growth in young subalpine fir plants in response to increased irradiance has been demonstrated $[26,27]$. Few seedlings exhibited growth in the understory at $10 \%$ of the open-sky light level, and a strong relationship was observed between the level of light and elongation growth [26]. Less bud set in the seedlings of this species was also reported when grown under higher compared with lower irradiance under controlled conditions [10]. Furthermore, if the increased BL proportion triggers responses normally associated with the acclimation to higher irradiances, as shown at least in roses [28], lower bud set may have been expected under the higher BL proportion. Thus, the reason for greater bud set in 30\% compared with 5\% BL remains elusive.

In subalpine fir, the shoot transpiration rate ( $\mathrm{mg} \mathrm{H}_{2} \mathrm{O}$ per needle) in response to additional $\mathrm{BL}$ was reduced, suggesting partly closed stomata (Table 2). BL is normally an opening signal for stomata, and Norway spruce responded to additional BL by increased transpiration. Light stress commonly induces stomatal closure and the fact that transpiration was reduced and that more terminal buds were observed in subalpine fir exposed to a higher BL proportion indicate they are less robust in response to BL than Norway spruce [29].

Species-dependent responses to light quality are often discussed in relation to light adaption [30]. Riikonen et al. [6] found a stronger response to light quality on the growth and morphology in the shade-intolerant Scots pine compared with the more shade-tolerant Norway spruce. Although Norway spruce are known to be shade-tolerant, the plants responded positively to increased BL in the photosynthetic light. Similarly, the shade-intolerant Scots pine seedlings exposed to a light treatment containing a high BL fraction ( $25 \%$ and $55 \% \mathrm{BL}$ ) had increased branching and thicker stems compared with those grown under a HPS light [6]. Furthermore, when the Scots pine seedlings were germinated under elevated BL treatments, the seedlings accumulated a higher biomass in the shoot as well as the root, and retained more water compared with the plants produced with less BL [29].

In the study of Riikonen et al. [6], taller Norway spruce seedlings were found under HPS compared with plants grown under 25\% BL and 55\% BL from LEDs. However, in our experiment, we did not observe any difference in the shoot length, although a higher number of needles, more branches, and a larger root system in the Norway spruce seedlings exposed to additional BL indicates a higher growth rate. Furthermore, increased BL changed the biomass distribution in Norway spruce and more DM was allocated to the roots, resulting in a highly branched, robust root system (Figures 2 and 3). The improved needle biomass development for the BL-exposed seedlings likely resulted in an increased photosynthetic capacity beneficial for the root development. BL as a signal perceived by the shoot could also affect the root architecture by adjusting the transport and/or response of plant hormones like auxin known to affect the branching capacity of roots [31]. A branched, robust root system is beneficial for a seedling's field performance [32].

In conclusion, the proportion of BL in the photosynthetic light is important to take into consideration when designing light spectra for conifer seedling production. A high proportion of BL (30\%) can induce stress and growth inhibition or improve the growth and development, depending on the species. 
Author Contributions: Formal analysis, S.T.; Investigation, H.N.; Methodology, S.T.; Project administration, I.S.F. and J.E.O.; Supervision, J.E.O. and S.T.; Writing-original draft, H.N.; Writing一review and editing, I.S.F., J.E.O. and S.T. All authors have read and agreed to the published version of the manuscript.

Funding: This research was funded by Norges Forskningsråd: 225365/E40.

Acknowledgments: We gratefully acknowledge the Norwegian Research Council (grant 225365/E40) and the Norwegian University of Life Sciences for funding.

Conflicts of Interest: The authors declare no conflict of interest.

\section{References}

1. Grossnickle, S.C. Why seedlings survive: Influence of plant attributes. New For. 2012, 43, 711-738. [CrossRef]

2. Grossnickle, S.C.; MacDonald, J.E. Why seedlings grow: Influence of plant attributes. New For. 2018, 49, 1-34. [CrossRef]

3. Chiang, C.; Aas, O.T.; Jetmundsen, M.R.; Lee, Y.; Torre, S.; Floistad, I.S.; Olsen, J.E. Day Extension with Far-Red Light Enhances Growth of Subalpine Fir (Abies lasiocarpa (Hooker) Nuttall) Seedlings. Forests 2018, 9, 175. [CrossRef]

4. Hernandez Velasco, M.; Mattsson, A. Light quality and intensity of light-emitting diodes during pre-cultivation of Picea abies (L.) Karst. and Pinus sylvestris L. seedlings - impact on growth performance, seedling quality and energy consumption. Scand. J. Forest Res. 2019, 34, 159-177. [CrossRef]

5. Riikonen, J. Efficiency of night interruption treatments with red and far-red light-emitting diodes (LEDs) in preventing bud set in Norway spruce seedlings. Can. J. For. Res. 2018, 48, 1001-1006. [CrossRef]

6. Riikonen, J. Pre-cultivation of Scots pine and Norway spruce transplant seedlings under four different light spectra did not affect their field performance. New For. 2016, 47, 607-619. [CrossRef]

7. Molmann, J.A.; Junttila, O.; Johnsen, O.; Olsen, J.E. Effects of red, far-red and blue light in maintaining growth in latitudinal populations of Norway spruce (Picea abies). Plant Cell Environ. 2006, 29, 166-172. [CrossRef] [PubMed]

8. Opseth, L.; Holefors, A.; Rosnes, A.K.R.; Lee, Y.; Olsen, J.E. FTL2 expression preceding bud set corresponds with timing of bud set in Norway spruce under different light quality treatments. Environ. Exp. Bot. 2016, 121, 121-131. [CrossRef]

9. Olsen, J.E. Light and temperature sensing and signaling in induction of bud dormancy in woody plants. Plant Mol. Biol. 2010, 73, 37-47. [CrossRef]

10. Chiang, C.; Olsen, J.E.; Basler, D.; Bankestad, D.; Hoch, G. Latitude and Weather Influences on Sun Light Quality and the Relationship to Tree Growth. Forests 2019, 10, 610. [CrossRef]

11. Taulavuori, K.; Sarala, M.; Taulavuori, E. Growth responses of trees to arctic light environment. In Progress in Botany; Lüttge, U., Beyschlag, W., Büdel, B., Francis, D., Eds.; Springer-Verlag: Berlin, Germany, 2010; Volume 71, pp. 156-168.

12. Huche-Thelier, L.; Crespel, L.; Le Gourrierec, J.; Morel, P.; Sakr, S.; Leduc, N. Light signaling and plant responses to blue and UV radiations-Perspectives for applications in horticulture. Environ. Exp. Bot. 2016, 121, 22-38. [CrossRef]

13. Ranade, S.S.; Gil, M.R.G. Application of monochromatic blue light during germination and hypocotyl development improves outplanted Scots pine (Pinus sylvestris L.) trees performance. For. Ecol. Manag. 2016, 361, 368-374. [CrossRef]

14. Lin, C.T. Plant blue-light receptors. Trends Plant Sci. 2000, 5, 337-342. [CrossRef]

15. Smith, H.; Whitelam, G.C. The shade avoidance syndrome: Multiple responses mediated by multiple phytochromes. Plant Cell Environ. 1997, 20, 840-844. [CrossRef]

16. Takemiya, A.; Inoue, S.; Doi, M.; Kinoshita, T.; Shimazaki, K. Phototropins promote plant growth in response to blue light in low light environments. Plant Cell 2005, 17, 1120-1127. [CrossRef]

17. Kaiser, E.; Ouzounis, T.; Giday, H.; Schipper, R.; Heuvelink, E.; Marcelis, L.F.M. Adding Blue to Red Supplemental Light Increases Biomass and Yield of Greenhouse-Grown Tomatoes, but Only to an Optimum. Front. Plant Sci. 2019, 9, 11. [CrossRef]

18. Sager, J.C.; Smith, W.O.; Edwards, J.L.; Cyr, K.L. Photosynthetic effciency and phytochrome photoequilibria determination using spectral data. Trans. ASAE 1988, 31, 1882-1889. [CrossRef]

19. Thomas B, V.-P.D. Photoperiodism in Plants, 2nd ed; Academic Press Inc.: San Diego, CA, USA, 1997. 
20. Mattsson, A.; Radoglou, K.; Kostopoulou, P.; Bellarosa, R.; Simeone, M.C.; Schirone, B. Use of innovative technology for the production of high-quality forest regeneration materials. Scand. J. Forest Res. 2010, 25, 3-9. [CrossRef]

21. Clapham, D.H.; Dormling, I.; Ekberg, I.; Eriksson, G.; Qamaruddin, M.; Vince-Prue, D. Latitudinal cline of requirement for far-red light for the photoperiodic control of budset and extension growth in Picea abies (Norway spruce). Physiol. Plant. 1998, 102, 71-78. [CrossRef]

22. Alakarppa, E.; Taulavuori, E.; Valledor, L.; Marttila, T.; Jokipii-Lukkari, S.; Karppinen, K.; Nguyen, N.; Taulavuori, K.; Haggman, H. Early growth of Scots pine seedlings is affected by seed origin and light quality. J. Plant Physiol. 2019, 237, 120-128. [CrossRef]

23. Landis, T.D.; Tinus, R.W.; McDonald, S.E.; Barnett, J.P. Atmospheric environment. In The Container Tree Nursery Manual, Agriculture Handbook 674; USDA Forest Service: Washington, DC, USA, 1992; Volume 3.

24. Knapp, A.K.; Smith, W.K. Factors influencing understory seedling establishment of engelmann spruce (Picea Engelmannii) and subalpine fir (Abies lasiocarpa) in Southeast Wyoming. Can. J. Bot.-Rev. Can. Bot. 1982, 60, 2753-2761. [CrossRef]

25. Mitamura, M.; Yamamura, Y.; Nakano, T. Large-scale canopy opening causes decreased photosynthesis in the saplings of shade-tolerant conifer, Abies veitchii. Tree Physiol. 2009, 29, 137-145. [CrossRef] [PubMed]

26. Klinka, K.; Wang, Q.; Kayahara, G.J.; Carter, R.E.; Blackwell, B.A. LIGHT-GROWTH RESPONSE RELATIONSHIPS IN PACIFIC SILVER FIR (ABIES-AMABILIS) AND SUB-ALPINE FIR (ABIES-LASIOCARPA). Can. J. Bot.-Rev. Can. Bot. 1992, 70, 1919-1930. [CrossRef]

27. Claveau, Y.; Messier, C.; Comeau, P.G.; Coates, K.D. Growth and crown morphological responses of boreal conifer seedlings and saplings with contrasting shade tolerance to a gradient of light and height. Can. J. For. Res.-Rev. Can. Rech. For. 2002, 32, 458-468. [CrossRef]

28. Terfa, M.T.; Solhaug, K.A.; Gislerod, H.R.; Olsen, J.E.; Torre, S. A high proportion of blue light increases the photosynthesis capacity and leaf formation rate of Rosa $x$ hybrida but does not affect time to flower opening. Physiol. Plant. 2013, 148, 146-159. [CrossRef] [PubMed]

29. Devireddy, A.R.; Zandalinas, S.I.; Gomez-Cadenas, A.; Blumwald, E.; Mittler, R. Coordinating the overall stomatal response of plants: Rapid leaf-to-leaf communication during light stress. Sci. Signal. 2018, 11, 9. [CrossRef]

30. Riikonen, J.; Kettunen, N.; Gritsevich, M.; Hakala, T.; Särkkä, L.; Tahvonen, R. Growth and development of Norway spruce and Scots pine seedlings under different light spectra. Environ. Exp. Bot. 2016, 121, 112-120. [CrossRef]

31. Vanneste, S.; Maes, L.; De Smet, I.; Himanen, K.; Naudts, M.; Inze, D.; Beeckman, T. Auxin regulation of cell cycle and its role during lateral root initiation. Physiol. Plant. 2005, 123, 139-146. [CrossRef]

32. Mattsson, A. Predicting field performance using seedling quality assessment. New For. 1997, 13, $227-252$. [CrossRef]

(C) 2020 by the authors. Licensee MDPI, Basel, Switzerland. This article is an open access article distributed under the terms and conditions of the Creative Commons Attribution (CC BY) license (http://creativecommons.org/licenses/by/4.0/). 